đúng vị trí trục loạn thị đã đánh dấu. Tính ổn định không xoay trục của TTTNT ART trong túi bao là vô cùng quan trọng bởi tính chính xác của kỹ thuật phụ thuộc phần lớn vào điều này. Các loại TTTNT toric thế hê đầu tiên được làm bằng chất liệu silicon và kích thước tổng thể của IOL không phù hợp đã làm cho IOL bị xoay trục nhiều, làm tăng loạn thị tồn dư sau phẫu thuật. Các loại TTTNT mới gần đây ra đời đã khắc phục được nhược điểm này và làm cho kết quả điểu trị ngày càng tăng lên. TTTNT ART được các tác giả báo cáo cho thấy độ trục IOL ít xoay và độ

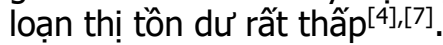

\section{KẾT LUÂ̂N}

Phẫu thuật đục TाT hiên nay được xem như một phẫu thuật khúc xạ để giải quyết tật khúc xạ có trước mổ, hơn là một phẫu thuật giải quyết TाT đục đơn thuần. Việc điều chỉnh loạn thị và kiểm soát loạn thị gây ra do phẫu thuật đã trở thành một phần không thể thiếu của kỹ thuật mổ TTT hiện đại trong đó Toric IOL là một lựa chọn hàng đầu cho nhiêu phẫu thuật viên nhãn khoa. Việc đă̆t Toric IOL vào đúng trục dự định là điều then chốt mang lại thành công cho phẫu thuật. Đánh giá độ xoay trục Toric IOL là một bước quan trọng trong việc theo dõi bệnh nhẩn sau phẫu thuật. Trục IOL xoay nhiêu sẽ dẫn đến độ loạn thị tồn dư nhiều và gây giảm thị lực của bệnh nhân.

\section{TÀI LIỆU THAM KHẢO}

1. Hayashi K, Shin-ichi Manabe, et al. (2010)
"Effect of astigmatism on visual acuity in eyes with a diffractive multifocal intraocular lens", ] Cataract Refract Surg, August, 36 (8): 1323-1329

2. Gangwani $V$, Hirnschall $N$, et al. (2014) "Multifocal toric intraocular lenses versus multifocal intraocular lenses combined with peripheral corneal relaxing incisions to correct moderate astigmatism", ] Cataract Refract Surg, Oct; 40 (10):1625-32.

3. Tiago B. Ferreira, Eduardo F. Marques, et al. (2013) "Visual and optical outcomes of a diffractive multifocal toric intraocular lens", ] Cataract Refract Surg, 39:1029-1035

4. Armando S. Crema, MD, PhD; Aileen Walsh, MD; Bruna V. Ventura, MD (2014) "Visual Outcomes of Eyes Implanted With a Toric Multifocal Intraocular Lens", J Refract Surg, 30(7):486-491

5. Bauer NJ, de V́ries NE, Webers CA, Hendrikse F, Nuijts RM. (2008) " Astigmatism management in cataract surgery with the Acry- Sof toric intraocular lens", ] Cataract Refract Surg; 34:1483-1488.

6. Holland $E$, Lane S, Horn JD, Ernest P, Arleo R, Miller KM. (2010) "The AcrySof toric intraocular lens in subjects with cataracts and corneal astigmatism; a randomized, subjectmasked, parallel-group,1-year study", Ophthalmology; 117:2104-2111

7. Viestenz A, Seitz B, Langenbucher A. (2005) "Evaluating the eye's rotational stability during standard photography; effect on deter- mining the axial orientation of toric intraocular lenses", ] Cataract Refract Surg; 31:557-561.

8. Jin H., Limberger, I.-J., Ehmer, A., Guo, H., \& Auffarth, G. U. (2010). "Impact of axis misalignment of toric intraocular lenses on refractive outcomes after cataract surgery", Journal of Cataract \& Refractive Surgery, 36(12), 2061-2072.

\title{
ĐĂC ĐIỂM TĂNG HUYẾT ÁP THAI KỲ VÀ MỐI LIÊN QUAN ĐẾN KẾT CỤC THAI KỲ CỦA BÀ ME NGƯỜI DÂN TỘC KHMER TỈNH TRÀ VINH
}

\author{
Phạm Văn Nhỏ*, Lê Minh Dũng*, Võ Minh Tuấn**
}

\section{TÓM TẮT}

Đặt vấn đề: Tăng huyết áp thai kỳ là một biên chứng nội khoa thường gặp, là một trong ba nguyên nhân gây tử vong hàng đẩu cho bà mẹ trên toàn thế giới. Mục tiêu nghiên cứu: Khảo sát đặc điểm tăng huyết áp thai kỳ và mối liên quan đến kểt cục thai kỳ của bà me dân tộc Khmer. Phương pháp nghiên cứu: Mô tả dọc hồi cứu 428 hồ sơ bệnh án bà mẹ dân tộc Khmer được chẩn đoán tăng huyết áp thai kỳ trong 3 năm 2018 - 2020. Kết quả nghiên cứu:

\footnotetext{
*Bệnh viện Sản - Nhi Trà Vinh

**Đai hoc Y Dước TP. Hồ Chí Minh

Chịu trách nhiệm chính: Võ Minh Tuấn

Email: Vominhtuan@ump.edu.vn

Ngày nhận bài: 9.4.2021

Ngày phản biện khoa học: 27.5 .2021

Ngày duyệt bài: 8.6.2021
}

Tăng huyết áp đơn thuân trong thai kỳ: 8,4\%. Nhóm tiền sản giật chiếm $87,2 \%$ (TSG có dấu hiệu nặng 47,2\%). Tiền sản giật trên người THA mạn tính: $2,1 \%$. Tăng huyết áp mạn tính: $2,3 \%$. Kết cục thai kỳ xấu chung (KCX): $27,3 \%$. Các yếu tố liên quan: Sản phụ sinh con thiếu tháng từ $34-<37$ tuần tăng nguy cơ gặp KCX cho cả me và bé gấp 4,1 lần (KTC 95\%: $2,1-8,7)$. Sản phụ sinh con thiếu tháng từ $<34$ tuần tăng nguy cơ gặp KCX cho cả mẹ và bé gấp 18,6 lần (KTC 95\%: 2,1-169,3). Sản phư có thiếu máu độ 2 tăng nguy cơ có KCX gấp 3,1 lần (KTC 95\%: 1,3-7,4). Kết Luân: Trong số THA thai kỳ, sản phu dân tộc Khmer có tỷ lệ $89,3 \%$ tiền sản giật cao hơn hẳn so với dân số chung khác.

Tư khóa: Tăng huyết áp thai kỳ, kết cục thai kỳ, bà mẹ dân tộc Khmer.

\section{SUMMARY \\ CHARACTERISTICS OF GESTATIONAL}




\begin{abstract}
HYPERTENSION AND ITS RELATIONSHIP TO PREGNANCY OUTCOMES OF KHMER ETHNIC MOTHERS IN TRA VINH PROVINCE

Background: Gestational hypertension is a common medical complication and is one of the top three causes of maternal death worldwide. Objective: To investigate the characteristics of gestational hypertension and its relationship to pregnancy outcomes of Khmer mothers. Methods: Retrospective longitudinal description of 428 medical records of Khmer mothers diagnosed with gestational hypertension in 3 years 2018 - 2020. Results: Simple hypertension in pregnancy: $8.4 \%$. Pre-eclampsia group accounted for $87.2 \%$. Presence of preeclampsia $47.2 \%$. Preeclampsia in people with chronic hypertension: $2.1 \%$. Chronic hypertension: $2.3 \%$. Overall bad pregnancy outcome: $27.3 \%$. Related factors: Pregnant women who give birth prematurely from 34 to $<37$ weeks have an increased risk of ER for both mother and baby 4.1 times (95\% CI: 2.1-8.7). Women who give birth prematurely from $<34$ weeks have an increased risk of ER for both mother and baby 18.6 times (95\% CI: 2.1-169.3). Pregnant women with grade 2 anemia have a 3.1 times increased risk of developing anemias (95\% CI: 1.3-7.4). Conclusion: Among Gestational Hypertension subjects, Khmer women have a rate of $89.3 \%$ of preeclampsia, which is much higher than that of the general population.
\end{abstract}

Keywords: gestational hypertension, pregnancy outcome, ethnic Khmer mothers

\section{I. ĐĂT VẤN ĐỀ}

Rối loạn tăng huyết áp thai kỳ là môt biến chứng nội khoa thường gặp nhất của người phụ nữ khi mang thai, trong đó chiếm tỷ lệ khoảng $10 \%$ thai kỳ là một trong ba nguyên nhân gây tử vong hàng đầu cho bà me trên toàn thế giới [5]. Các nghiên cứu ở trên thế giới, ở các dân tộc khác nhau có tỷ lệ rối loạn tăng huyết thai kỳ cũng khác nhau như nghiển cứu tại Trung Quốc $(2,2 \%)$, Hàn Quốc $(<7 \%)$ người Mỹ gốc Ân Độ $(8,9 \%)$, người da đen gốc Tây Ban Nha $(9,8 \%)$, người Mỹ bản địa $(5,6 \%)^{[6]}$. Một số nghiên cứu thực hiện tại bệnh viện Từ Dũ $(18,2 \%)$ bà mẹ có kết cục thai kỳ xấu ${ }^{[3]}$.

Trà Vinh là một tỉnh có đông đồng bào dân tộc Khmer trong cả nước, với Dân số Trà Vinh là 1.009.168 người, chiếm 5,84\% Đồng bằng sông Cửu Long (theo điều tra dân số năm 2019), trong đó $17,2 \%$ dân số sống ở khu vực đô thị và $82,8 \%$ dân số sống ở khu vực nông thôn. Với đặc điểm có đông người dân tộc Khmer, nghiên cứu của Phan Thanh Bình (2017), xác định tỷ lệ tăng huyết áp mãn tính ở người dân tộc Khmer từ 25 - 64 tuổi: 33,5\%, tỷ lệ bệnh phát hiện tăng huyết áp mới là $12,5 \%$ [4]

Bệnh viện Sản - Nhi Trà Vinh là một bệnh viện l̇oại II tuyến điều trị chuyên khoa Sản - Nhi cao nhất của tỉnh. Hằng năm bệnh viện tiếp nhận điều trị khoảng 30.000 sản phụ vào sinh. Tuy nhiên, chưa có nghiên cứu nào đánh giá đặc điểm rối loạn tăng huyết áp thai kỳ của sản phu Khmer tại tỉnh Trà Vinh với lý do đó, chúng tôi tiến hành: "Đặc điểm tăng huyêt áp thai kỳ và môi liên quan đến kêt cục thai kỳ của bà me người dân tộc khmer tỉnh Trà Vinh" Với câu hỏi nghiên cứu: "Đặc điểm tăng huyết áp ở thai phụ dân tộc Khmer tại Bênh viện Sản - Nhi Trà Vinh như thế nào?" Từ đó chúng tôi hiểu rõ hơn về đặc điểm lâm sàng và cận lâm sàng và quá trình chăm sóc thai nghén và kết cục của mẹ và bé để đưa ra các giải pháp nhằm nâng cao hiệu quả điêu tri, chăm sóc, hướng dẫn và quản lý thai nghén cho sản phụ người dân tộc Khmer bi bênh cảnh tăng huyết áp thai kỳ trên địa bàn tỉnh. Mục tiêu nghiên cứu

1. Xác định các hinh thái tăng huyêt áp thai kỳ ở bà me dân tộc Khmer đến sinh tại bệnh viện Sản - Nhi Trà Vinh năm 2018 - 2020.

2. Phân tích kết cục thai kỳ ở bà me dân tộc Khmer mắc tăng huyêt áp thai kỳ đến sinh tại bệnh viện Sản - Nhi Trà Vinh năm 2018 - 2020.

\section{II. ĐốI TƯợNG VÀ PHƯƠNG PHÁP NGHIÊN CứU}

- Thiết kế nghiên cứu: Mô tả dọc hồi cứu

- Đối tượng nghiên cứu: Tất cả HSBA các sản phụ người dân tộc Khmer có THA thai kỳ đến nhập viện và sinh tại Bệnh viện Sản - Nhi Trà Vinh từ 2018 - 2020.

- Tiêu chuẩn nhận vào

+ Phụ nữ người dần tộc Khmer

+ Được chẩn đoán mắc THA thai kỳ

+ Hồ sơ bệnh án đầy đủ thông tin.

- Tiêu chuẩn loại trừ: Thông tin trong hồ sơ bệnh án không rõ ràng, không chính xác, không có các xét nghiệm thường quy của phát đồ điều trị tại bệnh viện.

2.4. Cỡ mẫu. Chúng tôi ước tính cỡ mẫu một tỷ lệ trong quần thể với công thức:

$$
\begin{aligned}
& \mathbf{n}=\frac{\frac{z_{1-\infty / 2}^{2} \times \mathbf{p}(1-\mathbf{p})}{d^{2}}}{\text { - Khoảng tin cậy } 95 \%} \\
& \text { - d là độ chính xác lấy } d=0.05 \\
& \text { - } Z_{1-a / 2}=1.96
\end{aligned}
$$

- Chọn $p=0,5$ để đạt cỡ mẫu lớn nhất trong công thức $n=385$ sản phụ.

- Địa điểm và thời gian nghiên cứu

+ Đia điểm: Bênh viện Sản - Nhi Trà Vinh

+ Thời gian nghiên cứu: 10/2020 - 06/2021.

- Phương pháp chọn mẫu: Phương pháp chọn mẫu toàn bộ. Tất cả các HSBA sản phụ người dân tộc Khmer đến nhập viện và sinh tại 
Bệnh viện Sản - Nhi Trà Vinh trong giai đoạn 2018 - 2020.

\section{- Các bước thu thập số liệu:}

+ Bước 1: Tại phòng công nghệ thông tin sử dụng phần mềm máy tính quản lý HSBA, lọc tất cả các sản phụ dân tộc Khmer, đã sanh bị tăng huyết áp thai kỳ tại bệnh viện Sản - Nhi Trà Vinh từ 01/01/2018 - 31/12/2020 (Lấy số liệu ngược thời gian từ ngày $31 / 12 / 2020$ cho đến khi đảm bảo đủ mẫu tối thiểu 385 HSBA). Thực tế thu thập 428 HSBA đảm bảo đầy đủ thông tin theo bảng thu thập số liệu.

+ Bước 2 Lọc từ kho lưu trữ ra số thứ tự, mã số HSBA, họ tên và chữ lót, tuổi, dân tộc, năm nhập viện, mã bệnh lý: THA thai kỳ (O14) ; TSG (014.0); TSG nặng (014.1); Sản giật (015); hội Chứng HELLP (014.2), tăng huyết áp mạn tính (I10), TSG ghép trên tăng huyết áp mạn tính (011), theo mã ICD - 10.

+ Bước 3: Tại phòng kế hoạch tổng hợp lưu trữ HSBA của bệnh viện Sản - Nhi Trà Vinh, dựa trên danh sách đã lọc tất cả bệnh nhân, thu thập số liệu ngược dòng từ năm 31/12/2020 cho đến đủ cỡ mẫu đến năm 01/01/2018.

+ Bước 4: Tại phòng lưu trữ HSBA lấy mẫu thu thập thông tin nghiên cứu theo danh sách đã lọc và lấy từ năm, nếu bệnh án nào không đủ tiêu chuẩn nghiên cứu loại ngay lúc thu thập. Nghiên cứu viên và cộng tác viên đọc từng HSBA lọc các thông tin theo đúng yêu cầu của bảng thu thập số liệu đã đề ra.

+ Bước 5: Nhập, làm sạch, phân tích số liệu.

- Biến số nghiên cứu:

+ Theo phân loại theo Bộ Y tế Việt Nam năm 2021 có 4 nhóm THA trong thai kỳ bao gồm ${ }^{[1]}$ : 1. THA đơn thuần trong thai kỳ: $H A \geq 140 / 90$ $\mathrm{mmHg}$, đo 2 lần cách ít nhất 4 giờ, xuất hiện sau 20 tuần thai kỳ ở trường hợp có HA trước đó bình thường. Protein niệu (-) và không có triệu chứng nặng liên quan đến TSG. HA trở về bình thường sau sanh.

2. Tiền sản giật: là rối loạn chức năng nhiêu cơ quan liên quan đến thai nghén đặc trưng với

\section{KẾT QUẢ NGHIÊN CỨU}

\subsection{Phân loại THA trong thai kỳ (Bô y tế Việt Nam năm 2021)}

Bảng 1: Phấn loại THA trong thai kỳ

\begin{tabular}{|c|c|c|c|c|}
\hline STT & Nội dung & Tân số (n=428) & Tỷ lệ (\%) & KTC 95\% \\
\hline 1 & THA đơn thuần trong thai kỳ & 36 & 8,4 & $5,6-11,5$ \\
\hline 2 & TSG & 373 & 87,2 & $83,7-90,0$ \\
\hline & TSG có dấu hiệu nă̆ng & 202 & $(47,2)$ & $42,3-51,9$ \\
\hline & TSG không có dấu hiệu nặng & 171 & $(39,9)$ & $35,3-44,4$ \\
\hline 3 & TSG trên người THA mạn tính & 9 & 2,1 & $1,1-4,3$ \\
\hline 4 & THA mạn tính & 10 & 2,3 & $0,9-3,9$ \\
\hline
\end{tabular}

sự xuất hiện triệu chứng THA và protein niệu hoặc các triệu chứng lâm sàng liên quan đến tổn thương nhiều cơ quan do ảnh hưởng của TSG.

\section{TSG trên người THA mạn tính:}

+ THA mạn tính xuất hiện protein niệu sau 20 tuần thai kỳ.

+ THA mạn kèm protein niệu trước 20 tuần thai kỳ và xuất hiện THA đột ngột, biểu hiện tổn thương nhiêu cơ quan do ảnh hưởng của TSG.

4. THA man tính: THA trước khi mang thai hoặc THA trước 20 tuần thai kỳ.

+ Kết cục xấu mẹ: Khi me có tăng huyết áp kèm theo một trong bất kỳ dấu hiệu sau: Tử vong mẹ, sản giật, hội chứng HELLP, nhau bong non, tổn thương thận, phù phổi, xuất huyết não.

+ Kết cục xấu con : Khi có một trong các dấu hiệu sau: Thai nhẹ cân so với tuổi thai, thai chậm phát triển trong tử cung, thai chết lưu trong tử cung, tử vong sơ sinh.

+ Kết cục thai kỳ xâu chung: Khi me có kết cục thai kỳ xấu hoặc con có kêtt cục thai kỳ xâu hoặc cả hai.

+ Tuổi thai lúc sinh: Thời điểm trẻ được sinh ra trong lần sinh này đơn vị tuần.

+ Tình trạng thiếu máu: Thiếu máu độ 2 khi Hemoglobin < $10 \mathrm{~g} / \mathrm{dl}(100 \mathrm{~g} / \mathrm{l})$.

- Phân tích số liệu: Phần mềm thống kê STATA 10.0.

+ Tần số và phần trăm được tính toán cho những biến số định tính; trung bình và độ lệch chuẩn được sử dụng cho những biến số định lượng có phân phối bình thường.

+ Hồi quy logistic chính xác được sử dụng trong trường hợp xác định độ lớn sự kết hợp giữa biến số kết cục với những biến số độc lập có nhiều hơn 3 giá trị nhưng phải đòi hỏi giá trị

- Vấn đề đạo đức trong nghiên cứu: Nghiên cứu được chấp thuận của hội đồng đạo đức trong nghiển cứu y sinh học đại học Y Dược TP. Hồ Chí Minh theo Quyết định số: 777/HĐĐĐ-ĐHYD, ngày 27 tháng 10 năm 2020. trong đó $(p<0,2)$. 
Nhận xét: THA đơn thuần trong thai kỳ là 36 trường hợp chiếm tỷ lệ 8,4\% (KTC 95\%: 5,6 11,5). Sản phụ có TSG 373 trường hợp chiếm 87,2\% (KTC 95\%: 83,7 - 90,0). TSG trên người THA mạn tính có 9 trường hợp chiếm 2,1\% (KTC 95\%: 1,1 - 4,3). THA mạn tính có 10 trường hợp chiếm 2,3\% (KTC 95\%: 0,9-3,9).

\subsection{Phân bố kết cục tốt/ xấu thai kỳ}

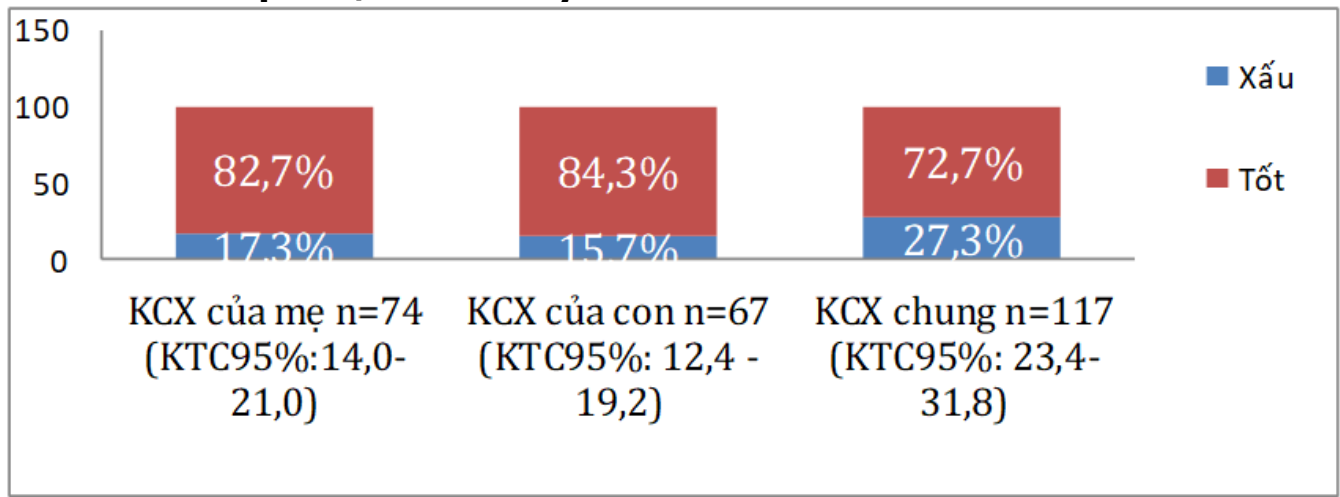

\section{Biểu đồ 3.1: Phân bố kêt cục thai kỳ tôt'/xấu}

Nhận xét: Phân bố kết cục thai kỳ tốt/xấu trong đó kết cục xấu của mẹ chiếm $17,3 \%$ và của con là $15,7 \%$. Kết cục xấu chung của mẹ và con là 27,3\%.

Sau khi phân tích hồi quy đơn biến cho các cặp biến số, để kiểm soát các yếu tố gây nhiễu và đồng tác, chúng tôi đưa biến số 16 biến số có $p<0,2$ vào phân tích đa biến. Nghiên cứu chỉ ra

3.3. Mối liên quan đến kết cục tốt/xấu của thai kỳ chung 3 biến số có mối liên quan thực sự đến kết cục xấu chung của mẹ và con.

Bảng 3.2: Mô hình hồi quy đa biến kết cục chung

\begin{tabular}{|c|c|c|c|c|c|}
\hline Đặc điểm & $\begin{array}{c}\mathrm{KCX} \\
\mathrm{n}=117(\%)\end{array}$ & $\begin{array}{c}\mathrm{KCT} \\
\mathrm{n}=331(\%)\end{array}$ & $\begin{array}{c}\text { OR thô } \\
\text { (KTC 95\%) }\end{array}$ & $\begin{array}{c}\text { OR hiệu chỉnh } \\
\text { (KTC 95\%) }\end{array}$ & p* \\
\hline \multicolumn{6}{|c|}{ Tuối thai lúc sinh } \\
\hline$\geq 37$ & $38(10,2)$ & $335(89,8)$ & 1 & 1 & \multirow{3}{*}{$\begin{array}{l}0,000 \\
0,009\end{array}$} \\
\hline $34-<37$ & $17(40,5)$ & $25(59,5)$ & $4,6(2,3-9,1)$ & $4,1(2,1-8,7)$ & \\
\hline$<34$ & $12(92,3)$ & $1(7,7)$ & $78,5(10,1-616,1)$ & $18,6(2,1-169,3)$ & \\
\hline \multicolumn{6}{|c|}{ Tình trạng thiếu máu } \\
\hline$<$ Độ 2 & $100(25,2)$ & $297(74,8)$ & 1 & $\frac{1}{21(1274)}$ & \multirow[t]{2}{*}{0,012} \\
\hline$\geq$ Độ 2 & $17(54,8)$ & $14(45,2)$ & $3,6(1,7-7,5)$ & $3,1(1,3-7,4)$ & \\
\hline
\end{tabular}

Nhân xét. Sản phụ sinh con thiếu tháng từ $34-<37$ tuần tăng nguy cơ gặp kết cục xấu cho cả me và bé gấp 4,1 lần (KTC 95\%: 2,1 - 9,9). Sản phụ sinh con thiếu tháng từ <34 tuần tăng nguy cơ gặp kết cục xấu cho cả me và bé gấp 18,6 lần (KTC 95\%: 2,1-169,3).Sản phụ có thiếu máu độ 2 tăng nguy cơ kết cục xấu gấp 3,1 lần (KTC:1,3-7,4).

\section{BÀN LUÂN}

Kết quả khảo sát tỷ lệ THA trong thai kỳ trên tổng số thai phụ đến sinh trong 3 năm 2018 2020 (từ 01/01/2018 - 31/12/2020) tại bệnh viện Sản - Nhi Trà Vinh đã tiếp nhận vào sinh khoảng 30833 sản phụ, có 1245 sản phụ bị THA trong thai kỳ là $4 \%$. Lưu tâm, trong số đó, sản phụ dân tộc Khmer vào sinh là 11367 , có 473 sản phụ bi THA trong thai kỳ chiếm tỷ lệ 4,2\% (KTC 95\%: $3,8-4,5)$. Thấp hơn kết quả nghiên cứu Huỳnh Minh Hồng [2] năm 2015 tỷ lệ THA trong thai kỳ tại bệnh viện Nhân Dân Gia Định là 8,72\% ${ }^{[2]}$

Sản phụ có TSG 373 trường hợp chiếm 87,2\% (KTC 95\%: 83,7 - 90,0) trong đó: tiền sản giật dấu hiệu nặng là 203 trường hợp chiếm
47,2\% (KTC 95\%: 42,3 - 51,9). Tiền sản giật không có dấu hiệu nặng chiếm 39,9\% (KTC 95\%: $35,3-44,4)$. Tình trạng sản giật trong nghiên cứu của chúng tôi có 4 trường hợp chiếm $0,9 \%$. Tương đồng khi so sánh với kết quả nghiên cứu của Nguyễn Thanh Hưng tỷ lệ sản giật là $0,9 \%{ }^{[3]}$.

THA mạn tính có 10 trường hợp chiếm 2,3\% (KTC 95\%: 0,9 - 3,9). Nhìn chung tỷ lệ THA mạn tính có sự tương đồng so với các nghiên cứu thực hiên tại Viêt Nam như nghiên cứu Huỳnh Minh Hồng và Châu Ngọc Hoa thực hiện năm 2015 trong đó THA mạn 2,01\% (3 trường hợp) ${ }^{[2]}$.

TSG trên người THA mạn tính có 9 trường hợp chiếm 2,1\% (KTC 95\%: 1,1-4,3). Thấp hơn 
so với nghiên cứu của Moussa HN (2017) ${ }^{[8]}$ là $11,0 \%$. Nguyên nhân có thể do các đối tượng TSG trên người THA mạn tính được dự phòng tốt TSG do biết trước bệnh lý tiền sử THA mạn tính (19 trường hợp THA mạn tính điều thực hiện khám thai định kỳ đây đủ). Nên tỷ lệ sản phụ có TSG trên người THA mạn tính thấp so với nghiên cứu khác.

Kết quả nghiên cứu của chúng tôi cho thây, tỷ lệ sản phụ người dân tộc Khmer có TSG cao hơn so với các nghiên cứu khác (tỷ lệ TSG trong nghiên cứu của chúng tôi là $89,3 \%$ ), cao hơn khi so với dân tộc khác (nghiên cứu của Akbar MIA là $79,3 \%$ ). Nguyên nhân, có thể do phát hiện THA trong thai kỳ trễ do quá trình khám thai không đầy đủ (46,5\% khám thai không đầy đủ), không được điêuu trị dự phòng TSG. Đa số các sản phụ dân tộc Khmer đến bệnh viện khi thai đủ tháng vào chuyển dạ sinh hoặc có vấn đề trong quá trình mang thai thì mới đến nhập viện.

Mối liên quan đến cục kết cục thai kỳ, qua phân tích đa biến 2 yếu tố có ảnh hưởng xấu đến thai kỳ trong thiếu tháng và thiếu máu ở mẹ. Vì vậy, việc khám thai định kỳ, theo dõi sát khi có bệnh lý phát sinh trong thai kỳ, bên cạnh đó tăng cường dinh dưỡng, kiểm soát thiếu máu ở bà me đặc biệt là bổ sung sắt trong thai kỳ theo khuyến cáo làm góp phần giảm kết cục thai kỳ xấu ở me và trẻ. Mối liên quan giữa thiếu máu trong thai kỳ và kết cục thai kỳ trong đó thay đổi sinh lý bình thường trong thai kỳ dẫn đến thay đổi các thông số huyết học, đặc biệt là làm giảm nồng độ hemoglobin. Do đó, hemoglobin được sử dụng để xác định thiếu máu trong thai kỳ thấp hơn ở bệnh nhân không mang thai. Do nhu cầu về sắt tắng lên trong thai kỳ, không có gì bất ngờ khi thiếu sắt vẫn là nguyên nhân phổ biến nhất của bệnh thiếu máu và đảm bảo cần phải có biện pháp xử lý trước để ngăn chặn việc giảm hemoglobin.

Số liệu nghiên cứu tập trung cho dân số đặc biệt là đồng bào Khmer, số liệu chỉ ra trong nhóm sản phu THA trong thai kỳ thì hình thái TSG chiếm tỉ lệ rất cao $89,3 \%$, cao hơn nhiều so với các nghiên cứu ở dân số chung Việt Nam. Điều này giúp ích cho những cán bộ sản phụ khoa và trung tâm kiểm soát bệnh tật ở tỉnh nhà, quan tâm hơn nữa về giáo dục sức khỏe sinh sản cho đồng bào Khmer, có kế hoạch phòng ngừa TSG sớm. Nghiên cứu của chúng tôi chỉ ra các yếu tố liên quan đến kết cục xấu thai kỳ của sản phụ dân tộc Khmer bị THA trong thai kỳ $(27,3 \%$ (KTC 95\%: 23,2 - 31,8). Dựa vào số liệu nghiên cứu, các cán bộ y tế có thể tư vấn và phòng ngừa sớm cho đồng bào Khmer vào những lần khám thai đầu tiên. Kết quả nghiên cứu này, làm tiền đề cho các nghiên cứu tiếp theo về công tác chăm sóc sức khỏe và chất lượng cuộc sông cho đồng bào dân tộc Khmer. Nghiên cứu thêm vào dữ liệu cho nghiên cứu sức khỏe sinh sản của phụ nữ Việt Nam.

\section{KẾT LUÂN}

Qua nghiên cứu của chúng tôi cho thãy sản phụ người dân tộc Khmer bị THA trong thai kỳ vào sinh có tỷ lệ tiền sản giật chiếm rất cao: 89,3\% (KTC95\%: 86,1-92) so với dân số chung Việt nam. Sản phụ sinh con thiếu tháng từ <34 $<37$ tuần tăng nguy cơ kết cục xấu cho cả mẹ và bé từ 4,1 - 18,6 lần so với đối tượng sinh con đủ tháng (mối liên quan có ý nghĩa thống kê p<0,05). Kết quả của Tracy A Manuck năm 2016 cho thấy trẻ sinh thiếu tháng tăng tỷ lệ tử vong sơ sinh [7]. Sản phụ có thiếu máu độ 2 tăng nguy cơ có kết cục xấu gấp 3,1 lần so với đối tượng không có thiếu máu (Mối liên quan có ý nghĩa thống kê $p<0,05)$. Kết cục thai kỳ xấu cho thai kỳ là: 27,3\% (KTC95\%: 23,4-31,8).

\section{TÀI LIẸU THAM KHẢO}

1. Bộ Y tế (2021), Quyết định số: 1911/ QĐ-BYT ngày 19 tháng 04 năm 2021 về việc ban hành tài liểu "Hướng dân Sàng lọc và điều trị dự phòng tiền sản giật", Hà Nội.

2. Huỳnh Minh Hî̀ng và Châu Ngọc Hoa (2017), "Khảo sát tỷ lệ và đặc điểm dân số tăng huyết áp thai kỳ tại Bệnh viện Nhân dân Gia Định", Tạp chí Y học TP HCM. 21(i), Trang:152.

3. Nguyê̂n Thanh Hưng, Phan Trung Hòa Võ Mính Tuấn (2020), "Kết cục thai kỳ và các yếu tố liên quan của những trường hợp được chẩn đoán tiên sản giật năng ở tuổi thai từ 28 đến 32 tuần tại Bệnh viện Từ Dũ", Tạp chí Y học TP HCM. 24(1), tr 83 - 90.

4. Phan Thanh Bình (2017), Thực trạng bệnh tăng huyết áp ở người Khmer và hiệu quả một số biện pháp can thiệp, luận văn tiến sỹ y tế cống cộng, Viện dịch tể Trung Ương, Hà Nội.

5. ACOG (2020), "Gestational Hypertension and Preeclampsia", ACOG Practice Bulletin,222.

6. Emergent Therapy for Acute-Onset (2019), " Severe Hypertension During Pregnancy and the Postpartum Period", ACOG. 767(133).

7. Gibbone E Marozio L, Polarolo G, Carbonara C, et al, (2016), "Expectant Management of Severe Preeclampsia Remote from Term: A Hospital-Based Survey", Ann Reprod Med Treat. 1(1), pp.1005-1011.

8. Leon MG Moussa HN, Marti A, Chediak A, Pedroza C, Blackwell SC, Sibai BM. (2017), "Pregnancy Outcomes in Women with Preeclampsia Superimposed on Chronic Hypertension with and without Severe Features", Am J Perinatol. 34(4), pp 403-408. 